\title{
DOES QURANIC RECITATION WORK ON A NON-AUDIBLE CELL? AN EXPERIMENTAL STUDY IN A MONOLAYER CELLS CULTURE MODEL
}

\author{
Rosyafirah Hashim ${ }^{1}$, Munirah Sha'ban ${ }^{2 *}$ \\ ${ }^{1}$ Department of Biomedical Science, Kulliyyah of Allied Health Sciences, \\ International Islamic University Malaysia, \\ Sultan Haji Ahmad Shah Street Kuantan, Pahang, Malaysia. 25200 \\ Email: rosyafirah@gmail.com \\ ${ }^{2}$ Department of Physical Rehabilitation Sciences, Kulliyyah of Allied Health Sciences, \\ International Islamic University Malaysia, \\ Sultan Haji Ahmad Shah Street Kuantan, Pahang, Malaysia. 25200 \\ *Email: munirahshaban@iium.edu.my
}

\begin{abstract}
There has been a dearth in modern scientific literature addressing the effect of Quranic recitation on the physical context of beings compared to a psychological or spiritual dimension. Muslims believe that the Holy Qur'an is Kalamullah (the words of God). This study distances itself from arguing the truthfulness of the Qur'an. Instead, it is an effort out of curiosity to appreciate the Creator's greatness from a scientist's perspective. It is always room for improvement in seeking knowledge. This study aimed to evaluate the effects of Quranic recitation on non-audible primary cells using a monolayer cell culture model. Cartilages were harvested from commercially available rabbits' knee joints $(n=6)$. The cartilage cells (chondrocytes) were isolated, cultured, and assigned to five groups. Three cultured chondrocyte groups were exposed to Sürat l-Fätîhah (The Opening), 'Arabic poem' and 'Western poem' recitals. Two other groups served as controls. One was exposed to a muted sound speaker (but switched on), and another group had no exposure. All recitations were recorded and exposed to the cells in a standardized, controlled condition to allow scientific rigor and a systematic approach. A scratch assay was also performed to mimic a simple wound healing model. Post-exposure evaluations included basic cellular staining, immunocytochemistry against collagen I and II, sulfated glycosaminoglycan (sGAG) production, and cartilage-specific gene expression analysis. All cells groups showed positive reactions to the various recitals exposures. However, based on the overall findings and chondrogenic properties preservation, the group exposed to the Qur'an exhibited better structure and function than the other groups. The results showed that the non-audible chondrocytes devoid of spiritual dimension could respond to vocal sounds. This non-invasive study indicates that a proper Quranic recitation has a healing effect and could impact physical cells better than the other recitals.
\end{abstract}

Keywords: chondrocytes, monolayer cells culture model, non-audible cell, Quranic recitation, Sürat l-Fätîhah

\begin{abstract}
Abstrak: Terdapat kelangkaan dalam literatur ilmiah modern yang membahas efek pembacaan Al Quran pada konteks fisik makhluk dibandingkan dengan dimensi psikologis atau spiritual. Muslim percaya bahwa Al-Quran Suci adalah Kalamullah (firman Allah). Kajian ini menjauhkan diri dari memperdebatkan kebenaran Al-Qur'an. Sebaliknya, merupakan upaya rasa ingin tahu untuk menghargai kebesaran Sang Pencipta dari sudut pandang seorang ilmuwan. Penelitian ini untuk mengevaluasi efek pembacaan Al Quran pada sel primer yang tidak dapat didengar menggunakan model kultur sel monolayer. Tulang rawan diambil dari sendi lutut kelinci yang tersedia secara komersial $(\mathrm{n}=6)$. Sel-sel tulang rawan (kondrosit) diisolasi, dibiakkan, dan dikelompokkan ke dalam lima kelompok. Tiga kelompok kondrosit yang dikultur disinari dengan pembacaan Sūrat 1-Fātihah (Pembukaan), 'puisi Arab' dan 'puisi Barat'. Dua kelompok lain berperan sebagai kontrol. Satu terpapar ke speaker suara yang diredam (tetapi diaktifkan), dan grup lain tidak terpapar. Semua bacaan direkam dan diekspos ke sel dalam kondisi standar dan terkontrol untuk memungkinkan ketelitian ilmiah dan pendekatan sistematis. Uji gores juga dilakukan untuk meniru model penyembuhan luka sederhana. Evaluasi pasca perlakuan dilakukan pewarnaan seluler dasar, imunositokimia terhadap kolagen I dan II, produksi glikosaminoglikan sulfat (sGAG), dan analisis ekspresi gen khusus tulang rawan. Semua kelompok sel menunjukkan reaksi positif terhadap berbagai paparan resital. Namun, berdasarkan temuan keseluruhan dan pelestarian sifat kondrogenik, kelompok yang terpapar $\mathrm{Al}$ Quran menunjukkan struktur dan fungsi yang lebih baik daripada kelompok lainnya. Hasil penelitian menunjukkan bahwa kondrosit non-audible tanpa dimensi spiritual dapat merespon suara vokal. Studi non-invasif ini menunjukkan bahwa pembacaan Al Quran yang tepat memiliki efek penyembuhan dan dapat berdampak pada sel-sel fisik yang lebih baik daripada pembacaan lainnya.
\end{abstract}

Kata Kunci: kondrosit, model kultur sel monolayer, pembacaan Al Quran, sel non-audible, Sūrat l-Fātiĥhah 


\section{Introduction}

Various academic and non-academic literature and customary discussions suggest a growing interest in minimal and non-invasive treatment modalities to achieve good health (Hashim et al., 2017). Other than opting for traditional and complementary medicine, there are claims, particularly in the Muslim world, that the Qur' an cures. In Tafsir ibn Katsir, besides being a compulsory 17 times recitation in the five obligatory prayers, Sürat l-Fätîhah has been described as 'asy-Syifa' and 'ar-Ruqyah' (Abu al-Fiḍā 'Imād Ad-Din Ismā'īl ibn 'Umar ibn Kathīr al-Qurashī Al-Damishqī, 2016). This description is supported by the meaning of a long Hadith narrating Prophet Muhammad (to have said: 'How did you know it (Sürat l-Fätihah) was Ruqyah (cure)?' (Jami`at-Tirmidhi 2064 n.d.). Plus, the Prophet (id not mention any prohibition against it (Sunan Ibn Majah 2156 n.d.). However, there has been a dearth in modern scientific literature addressing the effect of Quranic recitation on a physical body compared to the psychological or spiritual dimension. The positive, soothing effect was argued as sound healing. However, some beg to differ that the Quranic recitation is merely sound healing. This study aims to bridge that gap using a non-auditory cell to exclude effects on the hearing cell, tissue, or organ. Hence, the present work evaluated the effect of Quranic recitation on the growth of non-auditory cells, specifically the cartilage cells. An unwanted sound, i.e., occupational noise, was reported to have auditory and non-auditory consequences (Sheppard et al., 2020). Therefore, this present study will answer whether Quranic recitation works on a non-audible cell using an empirical, state-of-the-art monolayer cell culture model.

There are four primary types of mammalian tissue: epithelial, connective, muscle, and nervous tissue (Kenneth, Christina, and Heather 2021b). In this study, cartilage, a highly specialized connective tissue, was used. Besides being known for avascularity, cartilage comprises only one specialized cell type, i.e., chondrocyte $($ chondro $=$ cartilage + cyto $=$ cell) (Kenneth et al., 2021a). Chondrocyte was chosen as a candidate cell in this study because it is among the cells with low mitotic activity and is difficult to grow in vitro. The cell is sometimes identified as a degenerative cell because of its inability to regenerate well after injury. Histologically, the chondrocytes are housed in a lacuna, a micro space that clusters the cells and further limits nutrients and oxygen access from reaching them, especially those in the inner layer (Rim et al., 2020). Unlike epithelial cells that are highly proliferative and, given the above environmental characteristics, it is challenging to study this connective tissue cell and conclude the findings based on the morphology and growth only (Hashim et al. 2018). Following the "structure dictates function" notion in anatomy and physiology, the structural aspect validation for chondrocytes is well complemented with their functional conformation, i.e., their ability to produce cartilage-specific extracellular matrix (ECM) (Tahir et al., 2019; Nazir et al. 2020). It is essential to observe the ability of the chondrocytes to maintain their morphology and produce the ECM. It would be interesting to see how chondrocytes that do not possess any auditory property or equivalent system for the reception could respond to sound.

The first special sense to develop in a human embryo is hearing. It is recorded in a meaning of a hadith that "...When forty-two nights pass after the semen gets into the womb, Allah sends the angel and gives him shape. Then he creates his sense of hearing, sense of sight, his skin, hisflesh, his bones..." (Sahih Muslim 2645a n.d.). Modern scientific discovery of ear embryology and development confirmed the development timeline (Muhammad and Prasanna 2021). Indeed, many verses of the Qur'än, e.g., Sürat l-Insān (The Man, 76: 2), Sürat l-Mulk (The Sovereignty, 67: 23), and Sürat l-Sajda (The Prostration, 32: 9), mentioned the sense of hearing before the sense of sight (Yusuf Ali 2000). Regardless of hearing is passive and listening is active and engaged, sound has been a part of human life ever since in the mother's womb. A sound could enhance meaning, mood, improve energy levels and work-life balance (O'Callaghan et al., 2014). Sound healing applications can be dated back to ancient times (Devina, 2021). Apart from psychological or spiritual enhancement, a study reported that different sound exposures resulted in different growth rates on various orchid species (Sulong et al., 2016). They also deduced that sound could positively affect in vitro seed germination and plant growth. Another study suggested that human breast cancer cells showed cell growth arrest or apoptosis after exposure to sound (Lestard \& Capella 2016). These authors also agreed that sound would affect the auditory and non-auditory cells. The sound was used in the therapeutic strategy to improve the cell's proliferation in the hippocampus (Lee et al., 2016). It can also affect microbial growth and metabolism of an organism to a noticeable extent (Sarvaiya \& Kothari, 2015; 
Kothari, 2017). All these examples suggest that sound may directly or indirectly affect humans, physically and spiritually. Explaining the mode of action on how the cells responded to the sound and created biological effects remained a complicated and challenging task (Shaobin et al., 2010). Nonetheless, sound and cell interaction are exciting to explore, given the established potential.

Sound is like a mechanical wave that vibrates and propagates through fluids while producing pressure and displacement in the particle (Teijon et al., 2015). Three types of sound include infrasound, audible sound, and ultrasound which are calculated using frequency, $f$ measured in Hertz $(\mathrm{Hz})$. The application of infrasound and ultrasound is well documented, but the audible sound effect is still scarce. Thus, this present study used the audible sound as the primary variable to study the effect of the sound on the cell. Using sound in healing was started in ancient times and nurtured across time. It combines the use of sound to heal. Nowadays, studies related to sound healing are growing in numbers. Among the use of sound were in the development of delayed children, mentally ill adults, chronic disease patients, geriatric patients, and patients in psychotherapy (Lee et al., 2016). There are various explanations on how sound healing works, some of which come from modern science, others from a spiritual angle. Sound creates harmony and maintains order and discipline, which helps strengthen mental health (Frih et al., 2017). Based on the above explanations, it is suggestive that the human response towards sound is complex and might not be exclusive only to emotion (psychological aspect) but also to the cell (physical aspect).

In Islam, other than learning the advance seven Qira'at of the Qur'an, Tarannum is one of the disciplines that introduce the recitation of the Quranic verses with beautiful voices and melody without breaking the Tajwid (the correct pronunciation or sound in reading the Qur'an). While Tajwid literally means improvement and perfection, Tarannum is an art of recitation or voice in which rhythm is varied according to intonation and voice projection in harmonizing the sound. Reciting the Qur'an with Tarannum and giving rhythm to the Qur'an recitation are encouraged according to the commandment of the Prophet Muhammad (to recite the Qur'an with a sweet voice (Pejabat Mufti Wilayah Persekutuan, 2020). As indicated earlier in this paper, Quranic recitation has been used as a healing method since the times of Prophet Muhammad (The Qur'an is one of the revealed scriptures and included in the six articles or pillars of faith (Arkanul Iman). Based on the concept of faith in Islam, Muslims believe and accept that the Holy Qur'an is indeed Kalamullab (the words of Allah) (Mona \& Nahed, 2017). Muslims also believe in Hadith, another primary source of Islamic law (Shari 'ah) next to the Qur'an. This study distances itself from arguing the truthfulness or authenticity of the Qur'an and Hadith. The past Muslim scholars have responded to the authenticity issue accordingly. This study is an effort out of curiosity to appreciate the Creator's greatness from a scientist's perspective.

The previous preliminary work indicated a need to examine the effect of Quranic recitation on cell culture on a larger scale and include more details so that the study is scientifically sound (Hashim et al., 2018). The experiment above used only two samples (biological replicates) to analyze the growth kinetic profile of articular chondrocytes exposed to the Qur'an and Arabic poem recitations. Qualitatively, the growth of monolayer cultured cells results seem promising. However, the sample size was insufficient for a proper statistical analysis to conclude the findings. Thence, extending this work in progress approach (Hashim et al., 2018), this present study will complete the effort by adding more samples and analyses for scientific rigors. It is hypothesized that the exposure and incantation of a specific chapter of the Qur'an, namely Sürat l-Fätihah, would result in a healing effect on the cells better than the other exposure modalities used in this study. Another perplexing issue with cultured chondrocytes is that they often lose their chondrogenic properties in culture. This phenomenon is said to be associated with replicative senescence of cultured cells. Hence, this paper will also discuss whether Quranic recitation could help improve this aspect. In turn, if permissible by the religious authority and appropriate culturally, this methodology may be aligned with and support modern scientific fields progression such as tissue engineering and regenerative medicine, especially for the healing part.

\section{Materials and Methods}

The Institutional Animal Care and Use Committee (IA-CUC) of International Islamic University Malaysia (IIUM) [IUM/IACUCAPPROVAL/2015/(5)(24)] approved this study. 


\section{A. Monolayer Cell Culture Groups}

The chondrocytes were harvested from commercially available rabbits' knee joint cartilage. All sample handling and cell culture steps were based on the previous research protocols (Hashim et al., 2018; N. Md Nazir et al. 2019). The monolayer cultured cells were exposed to various sounds and divided into five groups (Table 1).

Table 1. Experimental and control groups assignment in this study

\begin{tabular}{cllc} 
Cells & \multicolumn{1}{c}{ Group } & \multicolumn{1}{c}{ Mode } & Group's Abbreviation \\
Monolayer cultured & Exposed to the & 1. Quranic recitation & QR \\
chondrocytes & & 2. Arabic poem recitation & APR \\
& & 3. Western poem recitation & WPR \\
& Non-exposed & 5. Speaker 'on' with no sound & Control
\end{tabular}

\section{B. Sound Exposure Preparation}

Sound recording, volume, and exposure environment settings were optimized and standardized before exposing the sounds to the cultured cells (Hashim et al., 2018; Rosyafirah., 2020).

The sound recording was done using a similar frequency to avoid bias in the frequency range. The same voice recorded the Qur'an, Arabic poem, and Western poem recitals. The reciter is proficient in all the languages used in this study. The voice was recorded inside a sound-proof room at the Audiology Clinic, Kulliyyah of Allied Health Sciences (KAHS), IIUM. The strength of the voice was measured and monitored by observing the recording frequency panel using Audacity version 2.3.3, a free and opensource digital audio editor and recording application software. The pre-recorded sounds were transferred to a digital speaker (DOSS SoundBox) and used throughout the study.

Different volumes might affect the results of the study due to different sound intensities. Hence, a constant volume (decibel, $\mathrm{dB}$ ) was determined to correspond to the usual conversation level. The intensity emitted from the speaker located at a fixed distance $(10 \mathrm{~cm})$ from the cell culture was measured using the sound level meter (3M Quest SoundPro, TSI Quest, Raeco Rents, LLC. Utah). Throughout the study, the selected sound intensity was $\sim 60 \mathrm{~dB}$ for all exposures (Quranic, Arabic, and Western Poems).

The cultured cells were exposed to each sound in a pre-warmed thermal container $\left(37^{\circ} \mathrm{C}\right)$. The container is a collapsible insulated bag (Tupperware, Tupperware Corporation, United States) lined with polyester (outer part) and aluminum (inner part). Following optimizations, this container was chosen because it generates lower noise and reduces echoes. The exposure duration of the various sounds to the cultured cells was set to 12 minutes (Hashim et al., 2018). This duration was equalized using the prerecorded Sürat l-Fätihah that was played 17 times based on the total Raka'ah of the five times daily prayers obligated upon Muslims.

C. Structural Observation

Microscopic: Chondrocytes' shape, size, and appearance were observed in the serial passage ' 0 ' (P0) to P3 under a light microscope (PrimoStar Carl, Zeiss, Germany). Changes in all groups were captured using a Dino-Eye Eyepiece Camera (AnMo, Electronics Corporation, Taiwan) and recorded as photomicrographs using the Dino-Eye Lite Software (AnMo).

Histology: The cells were fixed in 10\% neutral phosphate-buffered formalin (Surgipath, Leica, Leica Biosystems Richmond, Germany), processed, and embedded (Leica) for histology analysis. The cells were stained with Hematoxylin and Eosin (H\&E, Leica) to assess cell morphology. Alcian Blue/Nuclear Fast Red (Merck, Merck KGaA, Germany/SynTek, SynTek Laboratories, USA) was used to detect glycosaminoglycans (GAG) accumulation. Safranin O/Fast Green (Merck/SynTek) was to identify a proteoglycan-rich ECM deposition. The intensity of the Alcian Blue and Safranin O stains is proportional to GAG and proteoglycans production amount.

Immunocytochemistry: It observed collagen type II (Anti-Collagen Type II (Ab-1), Merck, Calbiochem, Germany) and collagen type I (Monoclonal Anti-Collagen, Type I, Sigma ${ }^{\circledR}$, Sigma-Aldrich Corporation, USA) expression. The protocol was carried out using the Ultratech HRP Streptavidin Biotin Universal 
Detection System and Ultratech AEC Chromogen kits protocols (Beckman Coulter, Beckman Coulter, Inc., USA).

D. Functional Observation

Cartilage-specific Gene Expression: The analysis was carried out using quantitative polymerase chain reaction (qPCR, CFX96 Touch $^{\text {TM }}$, Biorad, US). The descriptions for primers used (1st BASE, Singapore), i.e., collagen type II (COL2A1), SRY (sex-determining region Y)-box 9 (SOX9), and aggrecan-core protein $(A C A N)$, collagen type I (COL1 A2), and a housekeeping gene, hypoxanthine phosphoribosyltransferase 1 (HPRT1), were summarized in Table 2. The stepwise protocols, including total RNA extraction (TRIzol, Gibco, Life Technologies, USA), cDNA synthesis (Superscript ${ }^{\mathrm{TM}}$ II Reverse Transcriptase, Gibco and Gradient thermal cycler, TC-512, Techne, Inc., USA), qPCR, and gel electrophoresis (EC 300 XL, Thermo Scientific, USA and Alpha Imager HP System, Alpha Innotech, USA), were accomplished following the previous studies' methodology (Mohamad et al. 2017; Nazir et al., 2019; Nazir et al., 2020).

Table 2. The primers used in the quantitative RT-PCR analysis using SensiFAST TM SYBR No-ROX Kit. Note: F=forward and $\mathrm{R}=$ reverse primers; $\mathrm{bp}=$ basepairs.

\begin{tabular}{|c|c|c|c|}
\hline Genes & Primers 5’ $\rightarrow$ ‘3 & PCR products (bp) & NIH GenBank \\
\hline COL2A1 & $\begin{array}{l}\text { F: 5'-TGC AGG AGG GGA AGA GGT AT-3' } \\
\text { R: 5'-GGC AGT CCT TGG TGT CTT CA-3' }\end{array}$ & 123 & NM_001195671.1 \\
\hline SOX9 & $\begin{array}{l}\text { F: 5'-AAG ATG ACC GAC GAG CAG GA-3' } \\
\text { R: 5'-CGT GTA TTC TCG GTG TCG GA-3' }\end{array}$ & 116 & XM_008271763.2 \\
\hline$A C A N$ & $\begin{array}{l}\text { F: 5'-ACA CTG GCG AGT ACT GTG AC-3' } \\
\text { R: 5'-TGT GAA AGA GTC GCT GGC AT-3' }\end{array}$ & 95 & XM_008251722.2 \\
\hline COL1A2 & $\begin{array}{l}\text { F: 5'-GGT GGT TAC GAC TTT GGT TA-3' } \\
\text { R: 5'-GCA TCG ACT TCA TAG TCC TT-3' }\end{array}$ & 95 & NM_001195668.1 \\
\hline HPRT1 & $\begin{array}{l}\text { F: 5'-GCA GAC CTT GCT TTC CTT GGT-3' } \\
\text { R: 5'-GCA GGC TTG CGA CCT TGA C-3' }\end{array}$ & 62 & NM_001105671.1 \\
\hline
\end{tabular}

Sulfated Glycosaminoglycan (sGAG) Production: All samples were first digested with papain digestion solution $\left(125 \mu \mathrm{g} / \mathrm{ml}\right.$ of papain, $5 \mathrm{mM} \mathrm{L}$-cysteine, $100 \mathrm{mM} \mathrm{Na}_{2} \mathrm{HPO}_{4}, 5 \mathrm{mM}$ EDTA, pH 6.8) at $60^{\circ} \mathrm{C}$ for 16 hours (N. Md Nazir et al. 2019; Noorhidayah Md Nazir et al. 2020). Based on the manufacturer's protocol, the sGAG content was quantitatively analyzed using the sGAG Assay Kit (K-Assay ${ }^{\circledR}$, Kamiya Biomedical Company, USA).

E. Scratch Assay

The chondrocytes were cultured until they reached 90\% confluency. Carefully, the cells were scratched with a sterile pipet tip (Greiner Bio-One, Greiner Bio-One GmbH, Germany), producing a straight line. The edge of the scratch was smooth, and the resulting debris was removed using the culture media (Jonkman et al., 2014). A reference point was marked and created at the bottom of the 6-well culture plate Nunc $^{\mathrm{TM}}$, Thermo Scientific, USA) to maintain the same field for image acquisition. The scratched-cultured cells were exposed to various sounds based on the assigned groups. Changes in the scratched areas mimicking wound healing were recorded as photomicrographs every 24 hours for two days. Also known as wound healing assay, this procedure is a standard in-vitro technique for examining or probing collective cell migration in two dimensions (Jonkman et al., 2014). The images were analyzed quantitatively for wound healing parameters using ImageJ, open-source software for processing and analyzing scientific images developed by the National Institutes of Health (NIH, US).

f. Statistical Analysis

Statistical analyses of quantitative in-vitro data were performed using GraphPad Prism version 8.0. Differences between the five independent groups were measured using two-way ANOVA with a confidence level of $95 \%$. This test determined how the cell growth was affected by the two factors: the different sound exposure and different passages. Post-hoc analysis was performed using Dunnet multiple comparisons test. All data were expressed as meantstandard deviation (SD). $P<0.05$ is considered statistically significant. 


\section{Result and Discussion}

\section{A. Structural aspect}

Monolayer cultured chondrocytes exhibited a small, polygonal-like, or rounded structure at P0. However, their size and shape changed after serial passages. The cultured cells are bigger and elongated and become elliptical or spindle. They adopted a more fibroblastic-like trait at later passages. This phenomenon indicated a loss of chondrogenic potential in dedifferentiated chondrocytes. Also, it is often associated with replicative senescence. In this study, cultured chondrocytes in all groups demonstrated similar morphology throughout passages (Figure 1).

Cytological staining facilitates microscopic observation (Figure 2). Hematoxylin stains cells' nuclei bluish to purplish, while eosin stains cytoplasm pink. The structural changes to the cultured chondrocytes are more vibrant and well-defined in H\&E, Alcian Blue/Nuclear fast Red, and Safranin O/Fast Green than those in Figure 1. The serially passaged cells changed from small and polygonal-like to bigger fibroblastic-like cells throughout the culture. Some cells adopted a dendritic-like feature unlike the QR group and became flattened on the slides, especially in APR, WPR, SP, and control groups. Alcian Blue stains GAG blue, and nuclear fast red counterstains the cells on the slides, so GAG deposits are more distinguishable than the other structures. Minimal GAG deposition can be observed at the pericellular matrix area of the chondrocytes in all groups. On the contrary, no orange/red stain (Safranin O) on the slides indicating the cultured cells lack proteoglycan-rich ECM production. Structures in green color (fast green) are the cell and the nucleus.

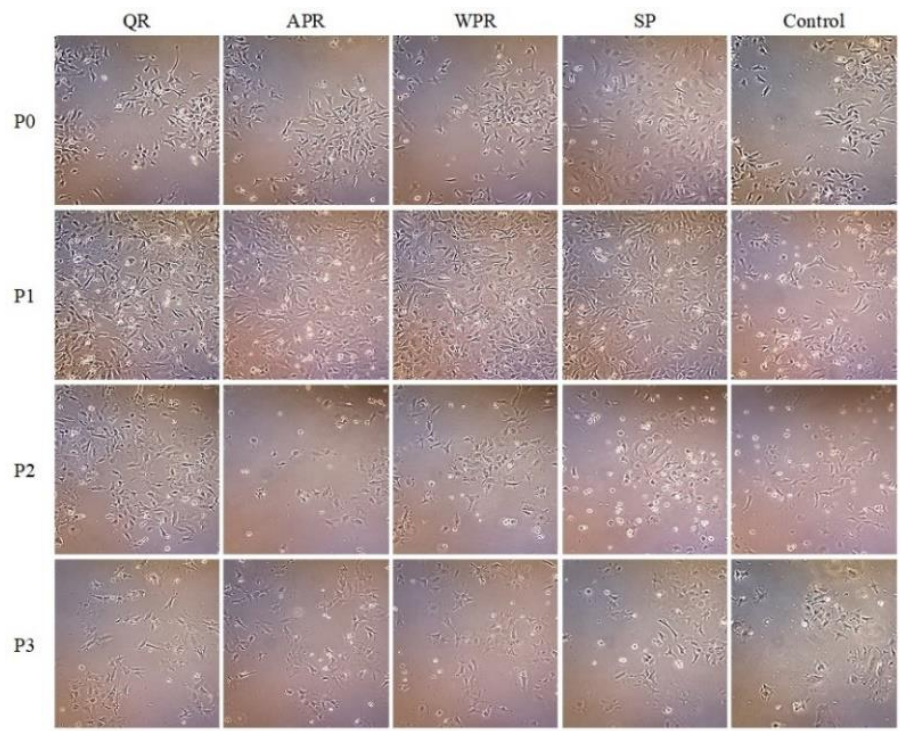

Figure 1. Chondrocytes in monolayer culture were exposed to various sounds (QR, APR, WPR, SP, and control) from P0 to

P3. Cultured cells exhibited a small polygonal-like appearance at $\mathrm{P} 0$ and later elongated and became spindle and more fibroblastic-like through passages. Some cells exhibited a dendritic-like appearance (Scale bar: $100 \mu$ m, magnification: 40×).

Cartilage-specific marker (collagen type II) and cartilage differentiation marker (collagen type I) were localized by brownish precipitation using immunocytochemistry (Figure 3). Collagen type II expression was detected in almost all groups throughout serial passages. The QR group showed better collagen type II expression than the other groups. Collagen type I was co-expressed in all groups throughout the passages. However, it is noticeable that the staining intensities were reduced at P3 for all groups. The difference in staining intensity differentiates the level of cartilage-specific ECM production. From the observation, the QR group showed better collagen type II and type I regulation than the other groups. 


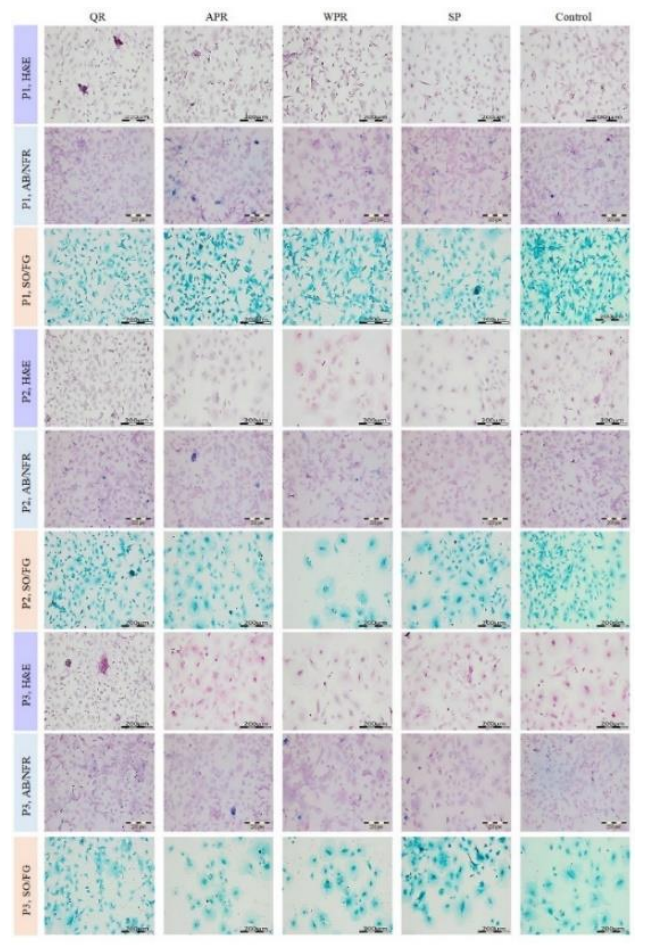

Figure 2. H\&E (row 1), Alcian Blue/Nuclear Fast Red (AB/NFR, row 2), and Safranin O/Fast Green (SO/FG, row 3 ) staining on monolayer cultured chondrocytes exposed with various sounds (QR, APR, WPR, SP, and control) from P1 to

P3. A very minimal GAG deposition stained blueish (Alcian Blue). A specific orange/red (Safranin O) stain for proteoglycan is not seen in the sections (Scale bar: $200 \mu \mathrm{m}$ : $100 \times$ magnification)

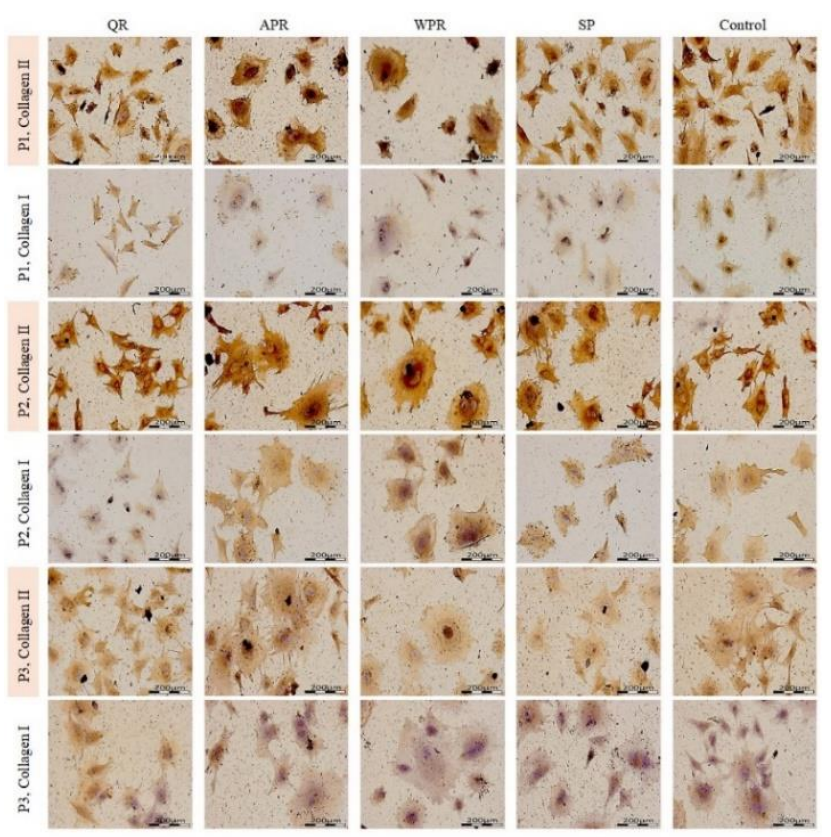

Figure 3. Immunocytochemistry against Collagen type II and Type I in all QR, APR, WPR, SP, and control groups. The brownish precipitation indicates a positive reaction. (Scale bar: $200 \mu \mathrm{m}$ : 100× magnification)

\section{B. Functional aspect}

COL2A1, SOX9, ACAN, and COL1A2 expression was quantified in all P0 to P3 monolayer cultured chondrocytes exposed with various sounds. Through gel electrophoresis validation, the PCR products of all genes resulted in different band intensities (result not shown). HPRT1 presence indicated that the analysis was reliable and successful. Quantitative PCR gives relative quantification of the genes 
based on $\mathrm{C}_{\mathrm{t}}$ or threshold cycle value (Applied Biosystem n.d.) normalized by the HPRT1. COL2A1 upregulation was seen only in the $\mathrm{QR}$ group at $\mathrm{P} 3$ with a fold ratio of $2.88 \pm 0.195$. SOX9 upregulation was noted at $\mathrm{P} 1$ in all groups with a fold ratio of $\mathrm{QR}=3.81 \pm 0.194, \mathrm{APR}=1.4 \pm 0.121$, WPR $=1.16 \pm 0.115$, $\mathrm{SP}=1.21 \pm 0.109$, and control $=1.64 \pm 0.166$. Meanwhile, $\mathrm{ACAN}$ upregulation was noted in all groups at $\mathrm{P} 2$ with a fold ratio of $\mathrm{QR}=6.01 \pm 0.173$, $\mathrm{APR}=1.43 \pm 0.107$, WPR $=0.65 \pm 0.141, \mathrm{SP}=1.04 \pm 0.166$, and control $=1.59 \pm 0.184$. COL1 $A 2$ upregulation was noted in all passages in all groups (Figure 4).

The sGAG quantification ( $\mathrm{ug} / \mathrm{ml}$ ) was performed for all five groups in all passages to measure the cartilaginous ECM production. The result shows the mean \pm SD comparing the differences between the sGAG content from P0 until P3 after various sound exposures. The results (ug/ml) are as follows: (1) QR group: $\mathrm{P} 0=0.14 \pm 0.02, \mathrm{P} 1=0.13 \pm 0.02, \mathrm{P} 2=0.15 \pm 0.02, \mathrm{P} 3=0.16 \pm 0.03$, (2) APR: $\mathrm{P} 0=0.11 \pm 0.01$, $\mathrm{P} 1=0.10 \pm 0.01, \mathrm{P} 2=0.11 \pm 0.01, \mathrm{P} 3=0.12 \pm 0.02$, (3) WPR: $\mathrm{P} 0=0.10 \pm 0.01, \mathrm{P} 1=0.09 \pm 0.01, \mathrm{P} 2=0.10 \pm 0.01$, $\mathrm{P} 3=0.11 \pm 0.02$, (4) SP: $\mathrm{P} 0=0.12 \pm 0.02, \mathrm{P} 1=0.11 \pm 0.02, \mathrm{P} 2=0.11 \pm 0.02, \mathrm{P} 3=0.12 \pm 0.02$, and (5) Control: $\mathrm{P} 0=0.11 \pm 0.01, \mathrm{P} 1=0.10 \pm 0.01, \mathrm{P} 2=0.11 \pm 0.02, \mathrm{P} 3=0.12 \pm 0.02$. The $\mathrm{QR}$ group showed significantly higher sGAG content in all passages $(\mathrm{P} 0: \mathrm{p}=0.0067 ; \mathrm{P} 1: \mathrm{p}=0.0087 ; \mathrm{P} 2: \mathrm{p}=0.0008$; and $\mathrm{P} 3$ : $\mathrm{p}=0.000)$ than the other groups.
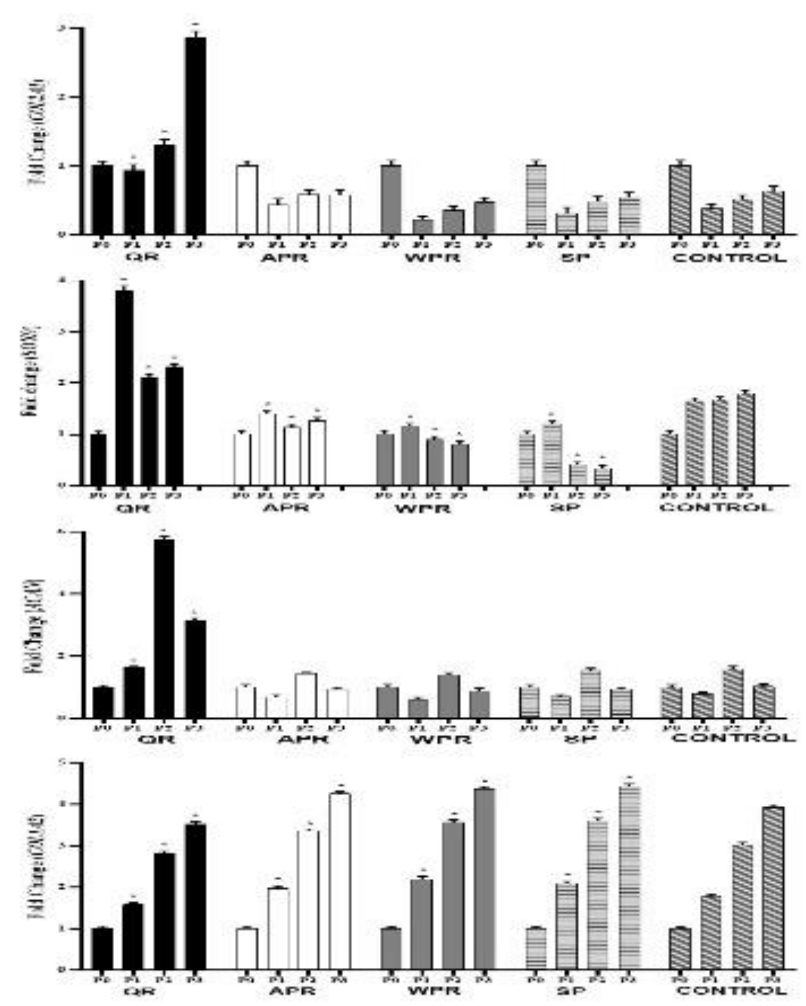

Figure 4. COL2A1, SOX9, ACAN, and COL1A2 genes expression normalized by HPRT1 for QR, APR, WPR, SP, and control groups. Data represent means of triplicate samples $(\mathrm{N}=6)$. The $*$ indicates significant values $(P<0.05)$. Error bars indicate standard deviations 


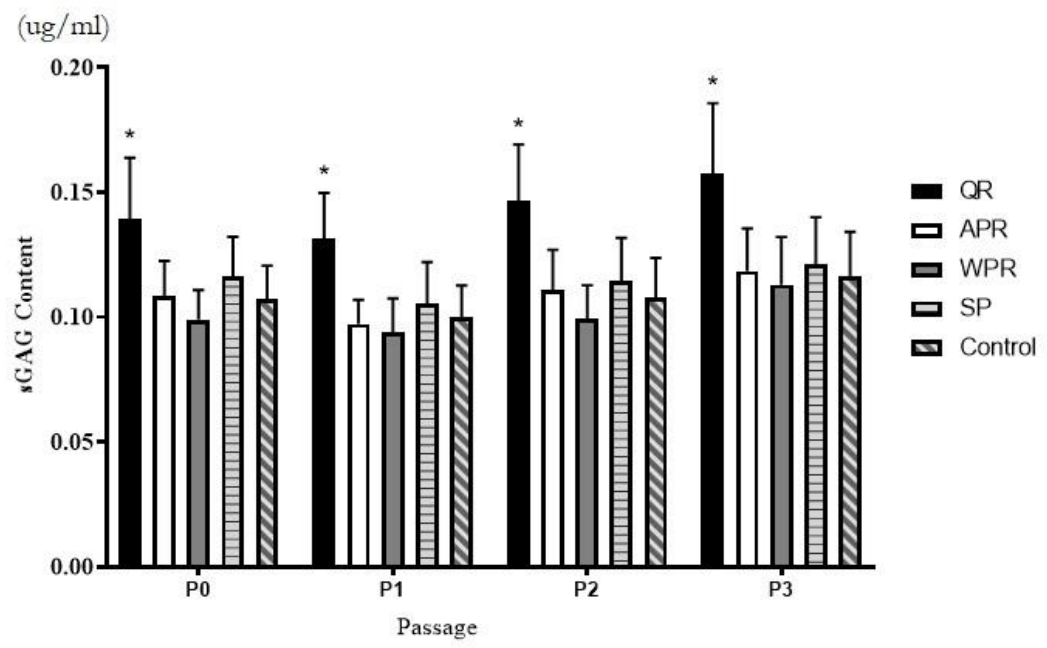

Figure 5. sGAG production (ug/ml) in all QR, APR, WPR, SP, and control groups. Data represent means of triplicate samples $(\mathrm{N}=6)$. The $*$ indicates significant values $(P<0.05)$. Error bars indicate $\mathrm{SD}$

\section{Wound healing}

The in-vitro wound healing assay of monolayer cultured chondrocytes showed that the mechanically created wound healed faster in the QR group than in the other groups. The images of the scratched cultured cells are given in Figure 6 . The results are shown as mean \pm SD comparing the differences between the percentage (\%) of wound closure after being scratched from P0 until P3 (Figure 7). The results for each group are as follows:

(1) QR group: $\mathrm{P} 0=43 \% \pm 0.013, \mathrm{P} 1=44 \% \pm 0.0091, \mathrm{P} 2=45 \% \pm 0.0097, \mathrm{P} 3=46 \% \pm 0.0097$, (2) APR: $\mathrm{P} 0=40 \% \pm 0.0083, \mathrm{P} 1=40 \% \pm 0.0097, \mathrm{P} 2=39 \% \pm 0.0007, \mathrm{P} 3=37 \% \pm 0.0161$, (3) WPR: $\mathrm{P} 0=37 \% \pm 0.0055$, $\mathrm{P} 1=35 \% \pm 0.0082, \quad \mathrm{P} 2=34 \% \pm 0.0009, \quad \mathrm{P} 3=34 \% \pm 0.0038$, (4) SP: $\mathrm{P} 0=39 \% \pm 0.013, \mathrm{P} 1=38 \% \pm 0.021$, $\mathrm{P} 2=37 \% \pm 0.015, \mathrm{P} 3=37 \% \pm 0.02$, and (5) Control: $\mathrm{P} 0=39 \% \pm 0.019, \mathrm{P} 1=38 \% \pm 0.018, \mathrm{P} 2=37 \% \pm 0.014$, $\mathrm{P} 3=37 \% \pm 0.012$. The QR group shows a statistically significant higher percentage $(\%)$ of wound closure than the others.

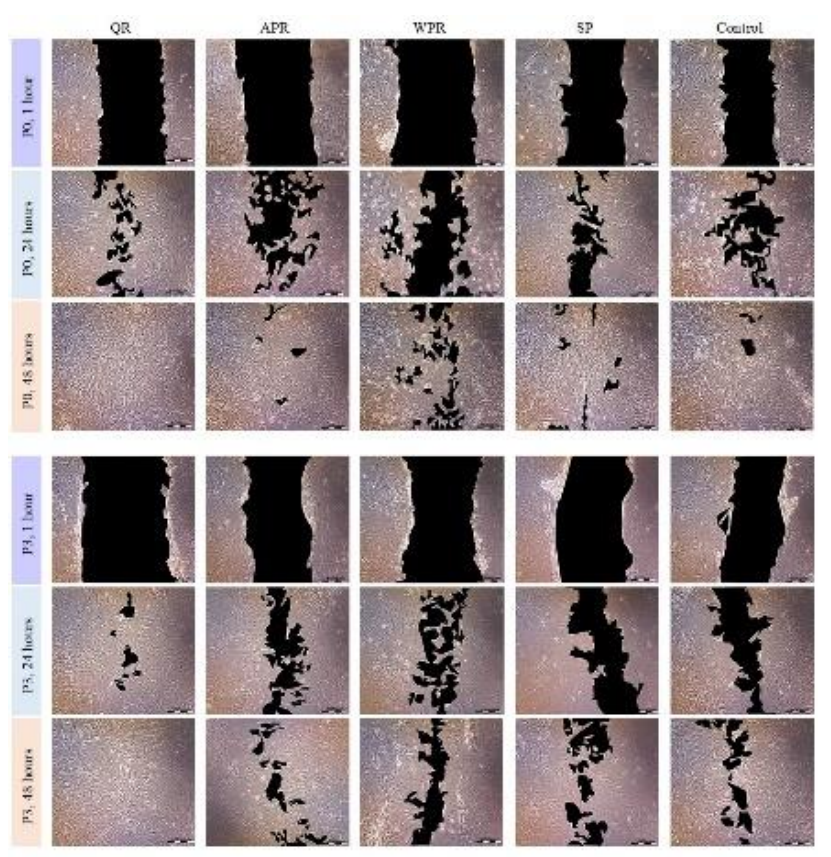

Figure 6. The scratched cells (leaving a dark, hollow area) mimic the wound created in all QR, APR, WPR, SP, and control groups. See wound closure progress from 0 to 48 hours of culture. The images are based on P0 and P3 cells since P1 and P2 cells exhibited a similar wound closure pattern (Scale bar: $100 \mu \mathrm{m}$ : 40× magnification) 


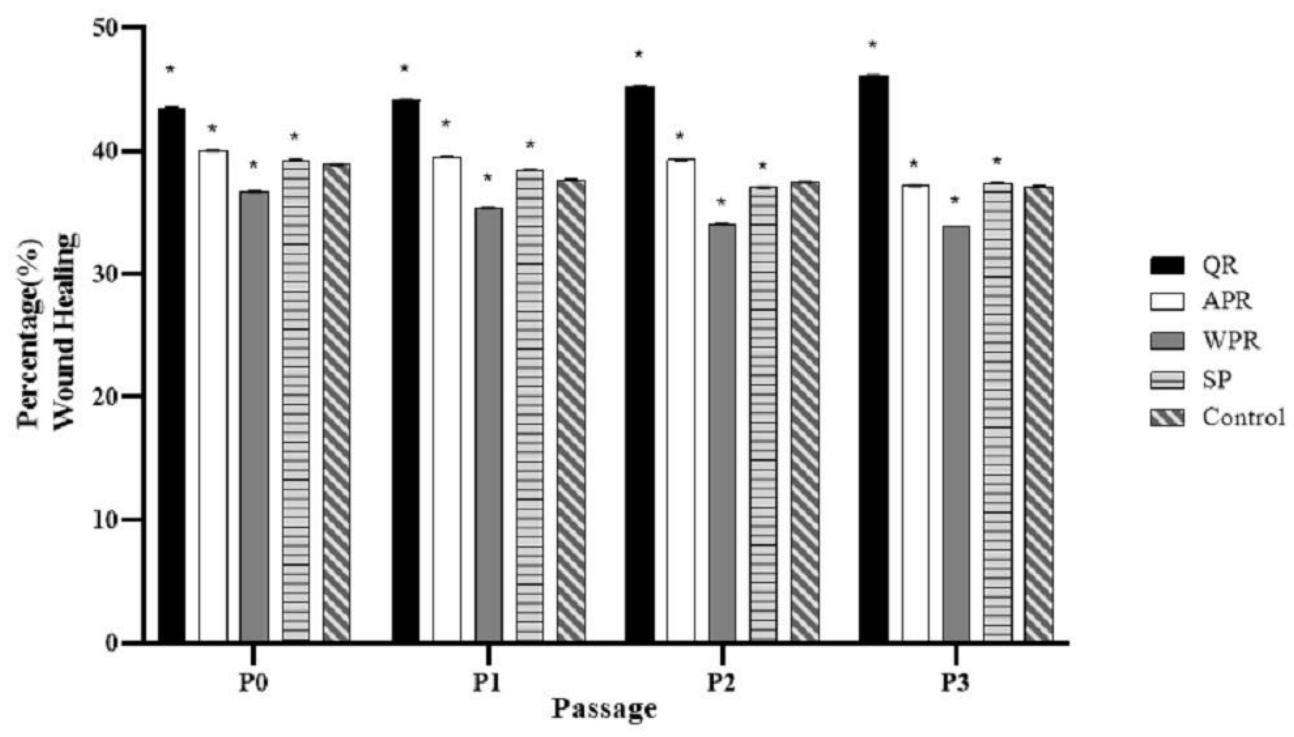

Figure 7. Wound closure was quantified in healing percentage (\%) from P0 to P3 in all QR, APR, WPR, SP, and control groups. Data represent means of triplicate samples $(\mathrm{N}=6)$. The $*$ indicates significant values $(P<0.05)$. Error bars indicate $\mathrm{SD}$.

A comparative analysis of various audible sounds was conducted in this present study. The sound exposure was standardized to keep the sounds within the same frequency before the actual experiment (Rosyafirah, 2020). All three sounds (Quranic verses, Arabic poem, and Western poem recitation) were set and recorded within the same frequency range between $0-12 \mathrm{kHz}$. However, it was noted that the frequency patterns for the three types of sound recorded were different. Similar to the wavelength of the sound, it can be observed that the wavelengths were in the same range (within human conversation level $\sim 60 \mathrm{~dB})$ but with a different pattern. This finding indicated that different sound within the same frequency range produces different patterns in frequency and wavelength. This finding suggests that the type of frequency and wavelength of the sound may play a significant consideration in the healing mechanism. The cellular response toward sound can depend on the nature of the sound (Lestard \& Capella 2016). A pilot study suggested that the action of the sound towards the test organism may be non-linear and show obvious frequency individualities (Shaobin et al., 2010). The mechanical vibration produced by the sound might cause mechanical stress either in positive or negative results on the cells (Lestard \& Capella 2016).

The paragraph above might indicate that different sound frequencies might provide different effects toward the chondrocytes. In this study, it can be noted that all different sounds that were used during the experiment had produced different frequency patterns. The difference in the effects of the sound frequencies towards the chondrocytes can be observed. Chondrocytes exposed to the Quranic recitation showed better effects than other sounds used. It is believed that the Quranic recitation is a natural sound produced by the human voice, which has unique qualities that can have positive effects on humans (Zulkurnaini et al., 2012). The Quranic recitation also has a powerful expression, fluent style, and captivating sound that affect the audience and has an inner tendency towards harmony and rhythm (Kamal et al., 2013). The recitations of the Holy Qur'an have been known to consist of various melodies or Tarannum (Tumiran et al., 2013). According to these authors, those melodious sounds show similarities with sound healing regarding the therapeutic effect. Possibly, the melodious sound produced during the Quranic recitation acts as sound healing.

The same voice can produce different frequencies during the sound recording. Differences in this frequency produced during the Quranic, Arabic, and Western poem recitation significantly affected the chondrocytes. This result supports a study that reported the frequency type affects differently on the healing power (Kamal et al., 2013). A similar result was reported where the human stem cells responded differently to the different frequency patterns of recorded voice on the same person (Ventura et al., 2017). 
Besides, similar findings to the sound differently on sound with different frequencies, amplitude, and intensity could produce a different response from the same organism (Kothari, 2017). The results in this present study suggest that the chondrocytes exposed to the Quranic recitation show the most favorable effects compared to the chondrocytes exposed to other sounds. It has been suggested that the effectiveness of sound healing will be different depending on the frequency range and the level of the sound used during the healing process (Erkkilä et al., 2011). This critical finding might suggest that the type of frequency of the sound plays a crucial consideration in the healing mechanism.

It was observed that the chondrocytes in initial passages (P0) in all groups were polygonal in shape and small in size. Throughout passages, the morphology of the cells in the APR, WPR, SP, and control groups increased in size. It changed its small, polygonal-like shape into bigger fibroblastic and dendriticlike cells from P0 to P3. This result was similar to a study where the authors stated that the shape of early cultured chondrocytes would appear small, flat, and irregular (Ma et al., 2013). However, they will become more fibroblastic and increase in size in later passages. However, in this study, most of the cells in the Quranic recitation group maintained cells' shape from P0 until P3. This finding might suggest that the Quranic recitation helps the chondrocytes maintain the monolayer culture's chondrogenic phenotype. The limitations during the monolayer expansion of the chondrocytes in vitro are to maintain their phenotype expression and differentiation ability (Melero-Martin \& Al-Rubeai, 2007). Hence, this study shows that the Quranic recitation offers a solution to overcome the limitations.

The subsequent structural and functional evaluations on the monolayer cultured chondrocytes were conducted using H\&E, Alcian Blue, Safranin O, and immunocytochemistry staining. The use of different staining methods was for a different purpose. For example, the H\&E was used to evaluate the overall structural aspect. Like the other special staining, Alcian Blue and Safranin O were used to assess the functional aspect of the cultured cells, i.e., the ECM production. Immunochemistry was used to detect the expression of cartilage-specific (collagen type II) and dedifferentiation (collagen type I). Based on the $H \& E$ staining, the cells showed excellent morphological appearance, similar to the previous study (Sarvaiya \& Kothari 2015). The cultured chondrocytes in all groups showed similar behavior throughout the passages, whereby in P3, the size of the cells was bigger than the P1 and P2 cells. However, the chondrocytes in the Quranic recitation group could maintain the initial morphology at all passages compared to the other groups. This result showed that the Quranic recitation helps the chondrocytes to maintain their shape and size until P3. It is perhaps an indication that the Quranic recitation had a positive effect in maintaining the morphology of the chondrocytes.

The bluish color of the Alcian blue staining indicates GAG production at the pericellular area of the chondrocytes. The nuclear fast red stained the nuclei pink. In a monolayer and 3D culture, healthy chondrocytes can secrete GAG at the pericellular area of the cultured cell (Munirah et al., 2008; Sha'ban et al., 2008). Alcian Blue staining findings showed the production of GAGs in all groups throughout the passages. Thus, it showed that all cultured chondrocytes could produce the GAGs, which is one of the essential components of the cartilage ECM. It indicates the presence of chondrogenic properties in all groups of chondrocytes. In this study, GAGs in the Quranic recitation group exhibited more intensity than in the other groups suggesting the ECM production was better than the other groups. The results showed no orange-red stain on the cells for Safranin O staining indicating all groups lack proteoglycan production. Proteoglycan is a long chain of GAGs (Kenneth et al., 2021a). The complex structure of proteoglycan with a higher affinity of the sulfur in cartilage may limit the Safranin O detection compared to the Alcian Blue. The insufficient presence of the proteoglycan in monolayer cultured chondrocytes is no more uncommon in many cartilage studies (Statham et al., 2021). It was suggested that culturing the cells in biomaterial scaffolds or introducing them to the three-dimensional environment can help the chondrocytes reinstate their properties to produce the proteoglycan (Munirah et al., 2008; Nazir et al., 2019; Nazir et al., 2020).

Collagen type II and type I immunolocalization were performed in all cultured chondrocytes groups from P1 to P3. Brownish precipitation can be seen at the pericellular matrix in all groups. The chondrocytes were able to sustain the expression of collagen type II throughout passages. The Quranic recitation group showed a more intense collagen type II expression than the other groups throughout all 
passages. The production of collagen type II is an excellent indicator to identify or study the chondrocytes (Munirah et al., 2010). Thus, the chondrocytes exposed to the Quranic recitation maintain their chondrogenic properties better than the chondrocytes in other groups. For cartilage dedifferentiation marker, i.e., collagen type I, brownish precipitation was also seen in all groups at P1 until P3. However, the expression showed a declining tendency at P3 for all groups. The co-expression of collagen type II and type $I$ in a particular ratio is typical in monolayer and $3 \mathrm{D}$ cultured chondrocytes in vitro(Marlovits et al., 2004). It was reported that collagen type II and type I will be co-expressed during bone and cartilage development in rats (Sasano et al., 2002) and a rat knee contracture model (Hagiwara et al., 2010). Even in some in vivo experimental settings, both collagen types would still be detected in the immature cartilage tissue undergoing a healing process (Cai et al., 2017).

An in-vitro wound healing model was established by a scratch assay using monolayer chondrocytes culture. The findings showed that the group exposed to Quranic recitation showed a more favorable healing effect than the other groups. It is suggestive that the chondrocytes exposed to Quranic recitation had an increase in cell proliferation and a reduction in healing time. This result confirms the study that suggests that sound can increase cell proliferation in autistic rat pups (Lee et al., 2016). This scratch assay results also mirrored the results in the growth kinetics profile. Chondrocytes in all groups proliferated and merged to close the gap or scratch induced in the middle of the culture plate during the assay. However, the chondrocytes exposed to the Quranic recitation showed better wound healing closure than other groups. The chondrocytes in the QR group required the shortest time to close the wounded area. This result can be related to the results obtained for population doubling time, as the cells exposed to the Quranic recitation require a shorter time to proliferate (Hashim et al., 2018; Rosyafirah, 2020). Thus, it can be suggested that the ability of chondrocytes to heal was faster in the QR group.

The gene expression profile characterizing the extracellular matrix is vital to understanding the chondrocytes' physiological and pathological state. This study evaluated the chondrogenic gene expression of the COL2A1, SOX9, and ACAN on the monolayer cultured chondrocytes. COL1A2 expression was constantly expressed in all chondrocytes. Upregulation was noted at every passage of the chondrocytes from P1 until P3 in collagen type I. A high COL1A2 upregulation suggested that chondrocytes exhibited a more fibroblastic trait at later passages. However, it subsided toward the P3. The chondrocytes in the Quranic recitation showed the lowest expression of collagen type I. This result supported the previous morphological result as the cells could sustain the shape of the cells. It is a normal phenomenon in cartilage research and documented in earlier studies (N. Md Nazir et al. 2019; Tew et al. 2005). The expression of collagen I and II in the cell culture showed the ability to maintain the phenotypic characteristics of the chondrocytes. The collagen type II in the Quranic recitation group showed an upregulation, specifically at P3. Significant upregulation was noted from the early and later passages. Other groups show downregulation at P1. Upregulation of the SOX9 was noted at P1 in all groups. For ACAN, upregulation was noted in all groups at P2. SOX9 plays a significant role in maintaining the morphology of the cultured cell from becoming a dendritic or fibroblastic-like structure. Thus, the results showed that the chondrocytes in the QR group could exhibit better chondrogenic markers expression than the chondrocytes in other exposed groups.

The sGAG analysis was conducted. This analysis indicates that there is a production of ECM in the cells. In this study, all chondrocytes exposed to different sound exposure increased in sGAG content. The chondrocytes exposed with the Quranic recitation show significantly higher sGAG content. The decrease in sGAG content indicates early osteoarthritis (OA), while increased content indicated that the chondrocytes had counteracted the degenerative processes (Abdul Rahman et al., 2015). An increase in the number of healthy cells will also increase the amount of sGAG content. It can be postulated that the chondrocytes in the QR group had overcome the senescence and become healthier toward the end of the passages. Thus, the Quranic recitation may overcome the degenerative disease of the chondrocytes.

Given all the above observations, the authors felt obliged to share an insight of the present work from the worldview of Islam. Muslims believe that the Holy Qur'an is a collection of God's words. This Kalamullah was revealed to Prophet Muhammad (through Jibril (also spelled Jabräil or Jibreel, in Islam-the archangel who acts as an intermediary between God and humans and as the bearer of 
revelation to the prophets) (Britannica, 2020). It is the most significant miracle (Mu'jizab) given to the Prophet Muhammad (the as it has stood the test of time. The Qursing and guidance for all of humanity. Muslims accept the Qur'an as one of the four revealed books, and this belief forms a pillar of Faith (Imän). Muslims accept the words in the Qur'an as the Words of Allab SWT without any doubts or reservations. In Sürat l-Jumu 'ah (Friday, 62:2), the purpose of the Quranic revelations was mentioned: "It is He who has sent amongst the unlettered people a messenger from among themselves, to rehearse to them His Signs, to purify them, and to instruct them in the scripture and wisdom-although they had been, before, in manifest error" (Ali, 2000). While these Revelations are sent down as (the way of) life's guidance, it also contains a cure and healing for ailments to those who believe. It is stated in Sürat l-Isrä (The Night Journey, 17:82), "We send down (stage by stage) in the Qur'an that which is a healing and a mercy to those who believe: to the unjust it causes nothing but loss after loss."

The Quranic recitation is a unique practice valued by Muslim communities worldwide. As stated in Sürat l-A 'räf (The Heights, 7:204), "So when the Qur'än is recited, then listen to it and pay attention that you may receive mercy." The Qur'än further tells humankind in Sürat l-An 'äm (The Cattle, 6:17), "And if Allah touches you with harm, none can remove it but He, and if He touches you with good, then $\mathrm{He}$ is Able to do all things." The lists continue with Sürat l-Shu 'arā (The Poets, 26:80): "And when I am ill, it is (God) who cures me." Also, in Sürat Muhammad (47:2): "But those who believe and work deeds of righteousness, and believe in the (revelation) sent down to Muhammad-for it is the Truth from their Lord-He will remove from them their ills and improve their conditions." Muslims believe that Allah $S W T$ has made the cure for every disease or illness (Mohammad Ateeq, Shazia Jehan, and Riffat Mehmmod 2014). In a meaning of a hadith narrated by Jabir ibn Abdullah: Allah's Messenger said, "There is a remedy for every malady, and when the remedy is applied to the disease it is cured with the permission of Allah, the Exalted and Glorious" (Sahih Muslim 2204 n.d.). Thus, the obligation to seek treatment has implications on the sufferers and those scientists involved in medical research to find the best treatment. A practicing Muslim has faith and a strong belief in the words of Allah SWT, as evident in the Qur'an.

Islam celebrates Dalil Naqli (based on the Qur'än and Haditb) and Dalil Aqli (based on 'Aql and reasoning). Modern science can provide some logical explanation on the healing properties mentioned in the Qur'an and Hadith. It is not always proper and necessary to verify the authenticity or truth of the Qur'an and Hadith through scientific means. Nonetheless, the productive relationship between Islam and science could help a Muslim strengthen and increase the faith in Allab SWT. From the Ahadith (Jami atTirmidhi 2064 n.d.; Sunan Ibn Majah 2156 n.d.), a healing characteristic exists in Sürat l-Fätiḩah. However, it is cautiously advised that it may not be permissible, from the religious point of view, to associate the utterance of the words of Allab SWT in terms of sound and sound healing. Furthermore, if it is merely "sound" as being interpreted as "something that one can hear" or "a medium that resulted from vibrations," then the element of healing that lies within the concept of Quranic recitation could be nullified. There may be areas yet to be uncovered that lie within those words that Allah SWT does not explain to humans. Look at the examples of certain introductory Arabic alphabets to begin 29 chapters of the Qur'ān that Muslim scholars to this day could not comprehend.

The present researcher remains steadfast to the Hadith mentioned above that Prophet Muhammad (1) approved the use of the Surat l-Fätihah as a cure (Ruquah). It is used to justify the possibility of Quranic recitation as a medium for healing involving the recitation that essentially is sound-taking that notion further, the need to associate sound in recitation to other "inner elements" that are expected within the recitation. The knowledge of Makhraj, Tajwid, Tarannum, and the seven styles of recitation (Qira'at) could make one look at the Quranic recitation beyond the voice (and thus the sound) recited the verse. The results may not be extrapolated or applicable to all humans' aspects. This study also does not suggest that anyone who recites the Sürat l-Fattihah over his illness will be cured. One might recite the Quranic verses in different ways. In this study, the application of the Quranic verses as the treatment only restricted in the form of sound healing. Unseen elements such as faith, hope, fear, and Khusyu'vary among individuals during the recitation, contributing to the healing potency. For instance, Quranic verses recited with faith that the disease will be cured (only by Allah's will) might differ from the recitation without faith. The 
same goes for the other elements that vary depending on the reciter. Spirituality level and the feeling of connectedness to Allah SWT during a recitation could cast an influence on the healing by the Holy Qur'an, for only Allah SWT knows. With that, the use of the term healing with the Quranic recitation to be a better nomenclature.

\section{Conclusion}

In this case, the Quranic recitation, Sürat l-Fätibhah, showed potential healing effects on the chondrocytes better than the other sounds used in this study. The connection between sound and cell needs to be studied further as it appears promising. The approach could pave the way for possible applications in treating articular cartilage injuries. It could be a potential approach for cartilage tissue engineering too. However, the results reported in this study are only based on the given experimental conditions. The results may vary depending on the sound types. For example, the results may not be the same if different Quranic verses and reciters are used. Regardless of the findings of this study have shown, the authors do not distance themselves from things that this study did not reveal, especially those spiritual aspects that relate to the Surrat l-Fätihah. They submit to the Wisdom and Knowledge of Allah SWT. Wallahu a'lam bish-shawabi.

\section{Acknowledgments}

The authors thanked the Ministry of Higher Education (MOHE) [MIRGS13-01-002-0003], the Ministry of Science, Technology, and Innovation (MOSTI) [SF14-012-0062], and IIUM for sponsoring research and facilities, IIUM Tissue Engineering and Regenerative Medicine Research Team, faculty members and individuals who helped materialize this study.

\section{References}

Abu al-Fị̣ā 'Imād Ad-Din Ismā̄ịl ibn 'Umar ibn Kathīr al-Qurashī Al-Damishqī. 2016. 1 Tafsir Ibnu Katsir. 9th ed. eds. E.M. M. Abdul Ghoffar et al. Jakarta, Indonesia: Pustaka Imam Asy-Syafi'i.

Ali, A.Y. 2000. The Holy Qur'an: Arabic Text with English Translation. Kitab Bhavan.

Applied Biosystem, ThermoFisher Scientific. "Real-Time PCR: Understanding Ct." Application Note: Real-time PCR. https://www.thermofisher.com/content/dam/LifeTech/Documents/PDFs/PG1503-PJ9169-CO019879-Re-brandReal-Time-PCR-Understanding-Ct-Value-Americas-FHR.pdf (July 26, 2021).

Ateeq, M., S. Jehan., R. Mehmmod. 2014. Faith healing; modern health care. The Professional Medical Journal 21(2): $295-301$.

Britannica, The Editors of Encyclopaedia. 2020. “Jibril.” Encyclopedia Britannica. https://www.britannica.com/topic/Jibril (July 24, 2021).

Cai, Linyi, Xin Xiong, Xiangli Kong, and Jing Xie. 2017. The Role of the Lysyl Oxidases in Tissue Repair and Remodeling: A Concise Review." Tissue Engineering and Regenerative Medicine 14(1): 15-30.

Erkkilä, J., M. Punkanen., J. Fachner., E. Ala-Ruona., I. Pöntiö, M. Tervaniemi., M. Vanhala., \& C. Gold. 2011. Individual music therapy for depression: randomised controlled trial. British Journal of Psychiatry 199(2): 132-139.

Frih, B., W. Mkacher., A. Bouzguenda., H. Jaafar., S.A. ALkandari., Z.B. Salah., B. Sas., M. Hammami., \& A. Frih. 2017. Effects of listening to holy qur'an recitation and physical training on dialysis efficacy, functional capacity, and psychosocial outcomes in elderly patients undergoing haemodialysis. Libyan Journal of Medicine 12(1): 1-7.

Hagiwara, Y., A. Ando., E. Chimoto., M. Tsuchiya., I. Takahashi., Y. Sasano., Y. Onoda., H. Suda., \& E. Itoi. 2010. Expression of collagen types I and II on articular cartilage in a rat knee contracture model. Connective Tissue Research 51(1): 22-30.

Hashim, Rosyafirah, M. Sha'ban, \& S.R. Z. I. Zainuddin. 2018. Identifying the Potential of Qur'anic Recitation on the Proliferation of Chondrocytes Derived from Rabbit Articular Cartilage: Work in Progress." IIUM Medical Journal Malaysia 17(1): 159-165.

Hashim, Rosyafirah, M. Sha'ban., \& Z. I. Zainuddin. 2017. Healing with Sound: Exploring Possible Applications of Qur'anic Recitation in Cell Culture." Revelation and Science 7(1): 32-41.

Jami at-Tirmidhi 2064. “Chapter 20: What Has Been Related About Taking Payment For Ta'widh (Incantation).” Book 28: Chapters on Medicine. https://sunnah.com/tirmidhi:2064 (July 23, 2021).

Jonkmana, J.E.N., J.A. Cathcarta., F. Xua., M.E. Bartolinia., J.E. Amonb., K.M. Stevensb., \& P. Colarussob. 2014. An introduction to the wound healing assay using live-cell microscopy. Cell Adhesion \& Migration 8(5): 440-451.

Kamal, N.F., N. H. Mahmood., \& N. A. Zakaria. 2013. Modeling Brain Activities during Reading Working Memory Task: Comparison between Reciting Quran and Reading Book. Procedia - Social and Behavioral Sciences 97: 83-89.

Kenneth., S. Saladin., A.G. Christina., N. C. Heather. 2021a. "Joints." In Anatomy \& Physiology: The Unity of Form and Function, New York: McGraw-Hill Education: 267-98.

. 2021b. "The Human Tissue." In Anatomy \& Physiology: The Unity of Form and Function, New York, NY 10121: McGrawHill Education: 137-73. 
Kothari, V. 2017. Audible sound in form of music can influence microbial growth, metabolism and antibiotic susceptibility. Journal of Applied Biotechnology \& Bioengineering 2(6): 212-219.

Lee, Sung-Min et al. 2016. Music application alleviates short-term memory impairments through increasing cell proliferation in the hippocampus of valproic acid-induced autistic rat pups. Journal of Exercise Rehabilitation 12(3): 148-155.

Lestard, N.R., and M.A. M. Capella. 2016. Exposure to music alters cell viability and cell motility of human nonauditory cells in culture. Evidence-Based Complementary and Alternative Medicine 2016: 1-7.

Ma, B., J.C.H. Leijten., L. Wu., M.Kip., C.A. van Blitterswijk., J.N. Post., M. Karperien. 2013. Gene expression profiling of dedifferentiated human articular chondrocytes in monolayer culture. Osteoarthritis and Cartilage 21(4): 599-603.

Marlovits, S., M. Hombauer., M. Truppe., V Vècsei., \& W. Schlegel. 2004. Changes in the ratio of type-I and type-II collagen expression during monolayer culture of human chondrocytes. The Journal of Bone and Joint Surgery. British volume 86(2): 286295.

Melero-Martin, J. M., and M Al-Rubeai. 2007. "Cartilage TE: In Vitro Expansion of Chondrocytes." In Topics in Tissue Engineering, ed. R Reis, E Chiellin N Ashammakhi. Biomaterials and Tissue Engineering Group: Oulu University, 1-37. https://www.oulu.fi/spareparts/ebook_topics_in_t_e_vol3/(July 25, 2021).

Mohamad, M.Y., M. A. Ifwat., M. Amin., A. F. Harun., N. Md. Nazir., M.A.A. Radzi., R. Hashim., N.F.M. Nawi., I. Zainol., A. H. Zulkifly., M. Sha'ban. 2017. Fabrication and Characterization of Three-Dimensional Poly(Lactic-Co-Glycolic Acid), Atelocollagen, and Fibrin Bioscaffold Composite for Intervertebral Disk Tissue Engineering Application. Journal of Bioactive and Compatible Polymers 32(5): 456-468.

Mona, M.El-Hady., \& A.K. Nahed. 2017. The effect of listening to Qur'an on physiological responses of mechanically ventilated muslim patients. IOSR Journal of Nursing and Health Science 6(5): 79-87.

Muhammad, H., \& T. Prasanna. 2021. “Embryology, Ear.” In StatPearls [Internet]., Treasure Island (FL): StatPearls Publishing LLC. https://www.ncbi.nlm.nih.gov/books/NBK557588/ (July 15, 2021).

Munirah, S., O.C. Samsudin., B.S. Aminuddin., \& B.H.I. Ruszymah. 2010. Expansion of human articular chondrocytes and formation of tissue-engineered cartilage: A step towards exploring a potential use of matrix-induced cell therapy. Tissue and Cell 42(5): 282-292.

Munirah, S., S.H. Kim., B.H. Ruszymah., \& G. Khang. 2008. The use of fibrin and poly (Lactic-co-glycolic acid) hybrid scaffold for articular cartilage tissue engineering: an in vivo analysis. European Cells and Materials 21(15): 41-52.

Nazir, N. M., A.H. Zulkifly., K.A. Khalid., I. Zainol., Z. Zamli., N. Sha ban. 2020. The cartilaginous tissue formation using sry (sex determining region Y)-BOX9 and telomerase reverse transcriptase genes transfected chondrocytes: in vivo approach. Sains Malaysiana 49(5): 1067-1080.

Nazir, N.M., A.H. Zulkifly., K. A. Khalid., I. Zainol., Z. Zamli., \& M. Sha'ban. 2019. Matrix production in chondrocytes transfected with sex determining region Y-Box 9 and telomerase reverse transcriptase genes: An in vitro evaluation from monolayer culture to three-dimensional culture. Tissue Engineering and Regenerative Medicine 16(3): 285-299.

O’Callaghan, C.C., F. McDermott., N. Michael., B.A. Daveson., P.L. Hudson., \& J.R. Zalcberg. 2014. A quiet still voice that just touches': music's relevance for adults living with life-threatening cancer diagnoses. Supportive Care in Cancer 22(4). 1037-1047.

Pejabat Mufti Wilayah Persekutuan. 2020. “Al-Kafi \#1725: The Ruling of Tarannum in Prayer." Al Kafi li al-Fatawi. https://muftiwp.gov.my/en/artikel/al-kafi-li-al-fatawi/4506-al-kafi-1725-the-ruling-of-tarannum-in-prayer (July 23, 2021).

Pulido Devina, L. 2021. “Sound Healing.” https://digitalcommons.csumb.edu/caps_thes_all/1079 (July 15, 2021).

Rahman, R.A., N.M. Sukri., N.M. Nazir., M.A.A. Radzi., A.H. Zulkifly., A.C. Ahmad., S.A. Rahman., \& M. Sha'ban. 2015. Evaluation of three-dimensional construct engineered from poly (Lactic-Co-Glycolic Acid)/ fibrin hybrid scaffold using rabbit bone marrow mesenchymal stem cells for osteochondral defect repair. Jurnal Teknologi 77(25): 77-82.

Rim, Y.A., Y. Nam., \& J.H. Ju. 2020. The role of chondrocyte hypertrophy and senescence in osteoarthritis initiation and progression. International Journal of Molecular Sciences 21(7): 1-15.

Rosyafirah, H. 2020. The Use of Monolayer Cultured Chondrocytes as a Cellular Model in Determining the Effect of Qur'anic Recitation on Primary Cells Growth in-Vitro. Thesis. International Islamic University Malaysia.

Sahih Muslim 2204. "Chapter 26: For Every Disease There Is A Remedy, And It Is Recommended To Treat Disease.” Book 39: The Book of Greetings. https://sunnah.com/muslim:2204 (July 24, 2021).

Sahih Muslim 2645a. "Chapter 1: How The Human Being Is Created, In His Mother's Womb, And His Provision, Lifespan And Deeds Are Written Down, And His Misery and Happiness." Book 46: The Book of Destiny. https://sunnah.com/muslim:2645a (July 15, 2021).

Sarvaiya, N., \& V. Kothari. 2015. Effect of audible sound in form of music on microbial growth and production of certain important metabolites. Microbiology 84(2): 227-235.

Sasano,Y., J-X. Zhu., M. Tsubota., I. Takahashi., K. Onodera., I. Mizoguchi., \& M. Kagayama. 2002. Gene expression of MMP8 and MMP13 during embryonic development of bone and cartilage in the rat mandible and hind limb. Journal of Histochemistry \& Cytochemistry 50(3): 325-332.

Sha'ban, M., S.H. Kim., R.B.H. Idrus., \& G. Khang. 2008. Fibrin and poly(Lactic-co-glycolic acid) hybrid scaffold promotes early chondrogenesis of articular chondrocytes: An in vitro study. Journal of Orthopaedic Surgery and Research 3(17): 1-10. 
Shaobin, G., Y. Wu., K. Li., S. Li., S. Ma., Q. Wang., \& R. Wang. 2010. A pilot study of the effect of audible sound on the growth of Escherichia coli." Colloids and Surfaces B: Biointerfaces 78(2): 367-371.

Sheppard, A., M. Ralli., A. Gilardi., \& R. Salvi. 2020. Occupational Noise: Auditory and Non-Auditory Consequences." International Journal of Environmental Research and Public Health 17(23): 1-15.

Statham, P., E. Jones., L. M. Jennings., \& H.L. Fermor. 2021. Reproducing the biomechanical environment of the chondrocyte for cartilage tissue engineering. Tissue Engineering Part B: Reviews.

Sulong, N.A., N.I.M. Khalil., M.I. Dahari., A.A. Zakaria. 2016. Effect of different sound genres on seed germination of and orchids. The Open Conference Proceedings Journal 7(1): 94-103.

Sunan Ibn Majah 2156. "Chapter 7: The Wages If The Raqt." Book 12: The Chapters on Business Transactions. https://sunnah.com/ibnmajah:2156 (July 23, 2021).

Tahir, M. A., A. Hanani., M. A. I. M. Amin., A. Azhim., \& M. Sha'ban. 2019. "Structural and Functional Properties of Neocartilage Construct Engineered in Poly (Lactic-Co-Glycolic Acid) (PLGA) Based Scaffolds.” International Journal of Integrated Engineering 11(3): 109-118.

Teijon, M.L., C. Castello., \& M. Asensio. 2015. Improvement of fertilization rates of in vitro cultured human embryos by exposure to sound vibrations. Journal of Fertilization: In Vitro - IVF-Worldwide, Reproductive Medicine, Genetics \& Stem Cell Biology 03(04): 1-6.

Tew, S.R., Y. Li., P. Pothacharoen., L.M. Tweats., R.E. Hawkins., \& T.E. Hardingham. 2005. Retroviral transduction with SOX9 enhances re-expression of the chondrocyte phenotype in passaged osteoarthritic human articular chondrocytes. Osteoarthritis and Cartilage 13(1): 80-8.

Tumiran, M.A., S.P. Mohamad., R.M. Saat., M.Y.Z.M. Yusoff., N. N.A. Rahman., \& D.S.H. Adli. 2013. Addressing sleep disorder of autistic children with Qur'anic sound therapy. Health 05(08): 73-79

Ventura C., Gullà D., Graves M., Bergonzoni A., Tassinari R., \& von Stietencron J. 2017. Cell melodies: When sound speaks to stem cells." CellR4 5(2): e2331-1-9.

Zulkurnaini, N.A., R.S.S.A. Kadir. Z. H. Murat., \& R.M. Isa. 2012. The comparison between listening to al-Quran and listening to classical music on the brainwave signal for the alpha band. In 2012 Third International Conference on Intelligent Systems Modelling and Simulation, IEEE. 